\title{
Complexity of Resiliency Framework for Refugee Population: A Letter to the Editor Regarding Wright et al. (2016)
}

\author{
Bediha Ipekci ${ }^{1}$ (])
}

Published online: 19 January 2018

๑) Springer Science+Business Media, LLC, part of Springer Nature 2018
Researchers disagree on how to operationalize resilience and its dimensions (e.g. trait or process) [3]. Wright et al. [7] utilized Resiliency Scale (RS) [5], focusing on individual characteristics including equanimity, perseverance, selfreliance, meaningfulness, and existential aloneness. The RS scale fails to recognize the role of supportive relationships and external influences and relies on characteristic traits, which do not adequately capture the experience of refugees [4]. Even though personal agency is necessary to handle adversity, the presence of resources from family and community is imperative [6].

Pangallo et al. [3] proposed an interactionist theoretical framework focusing on ecological and sociocultural domains, developmental influences upon complex interaction of internal (individual) and external (environment) resources. Similarly, according to Tummala-Narra [4], a cross-cultural perspective to resilience entails analysis of multiple phenomena such as individual development, community impact, and cultural systems of thought. She maintains that "cultural attitudes and ideals play an important role in fostering and helping to maintain resilience in the aftermath of trauma. Conceptions of the self in relationship to the external world and of the nature of traumatic experience vary considerably across cultures" (p. 37). In this article, the researchers might have considered that the RS scale was developed with a US sample [5], and greatly focuses on individual factors, suggesting it might not be suitable for Iraqis. In the measures section, Wright et al. [7] asserted that prior researchers have used the RS to measure resilience in refugee populations [2], including resilience in Iraqi refugees [1]. However, Li et al. [2] concluded that resilience did not

Bediha Ipekci

Bediha.Ipekci001@umb.edu

1 Counseling Psychology Program, College of Education and Human Development, University of Massachusetts Boston, 100 William T Morrissey Blvd, Boston, MA 02125, USA lead to decreases in psychological distress among refugees. Similarly, Arnetz et al. [1] reported that the hypothesis of resilience as a protective factor against psychological distress and PTSD symptoms was only partially confirmed.

The authors are to be commended for their exploration of the role of resilience in a refugee context, as very little research has been done on this topic to date. The authors' overreliance on a self-report resiliency measure, failing to recognize dynamic interactionist phenomenon as well as an ecological/contextual perspective, influenced by middle class, North American values, falls short of addressing cultural forms of resilience and adaptation among Iraqi refugees.

\section{References}

1. Arnetz J, Rofa Y, Arnetz B, Ventimiglia M, Jamil H. Resilience as a protective factor against the development of psychopathology among refugees. J Nerv Ment Dis. 2013;201(3):167-72. https:// doi.org/10.1097/NMD.0b013e3182848afe.

2. Li W, Cooling L, Miller DJ. Resilience, posttraumatic growth, and refugee mental health in Australia. In: American Psycho- logical Association Annual Convention. From: American Psychological Association Annual Convention; 2013. 31 July-4 August 2013, Honolulu.

3. Pangallo A, Zibarras L, Lewis R, Flaxman P. Resilience through the lens of interactionism: a systematic review. Psychol Assess. 2015;27(1):1-20. https://doi.org/10.1037/pas0000024.

4. Tummala-Narra P. Conceptualizing trauma and resilience across diverse contexts. J Aggress Maltreatment Trauma. 2007;14(12):33-53. https://doi.org/10.1300/J146v14n01_03.

5. Wagnild GM, Young HM. Development and psychometric evaluation of the Resilience Scale. J Nurs Meas. 1993;1:165-178

6. Windle G, Bennett KM, Noyes J. A methodological review of resilience measurement scales. Health Qual Life Outcomes. 2011;9(1):8. https://doi.org/10.1186/1477-7525-9-8.

7. Wright AM, Talia YR, Aldhalimi A, Broadbridge CL, Jamil H, Lumley MA, et al. Kidnapping and mental health in Iraqi refugees: the role of resilience. J Immigr Minor Health. 2016. https:// doi.org/10.1007/s10903-015-0340-8. 